\title{
Cytotoxicity of carnosine, taxifolin, linalool and their combinations with acids to the cells of human cervical carcinoma (HeLa)
}

\author{
Anita Rokaityte $\dot{1}^{*}$, \\ Gintarè Zaborskiené $\dot{e}^{1,2}$, \\ Violeta Baliukoniené ${ }^{1}$, \\ Jurgita Jovaišiene $\dot{1}^{1}$ \\ Sonata Gustien $\dot{e}^{1}$ \\ ${ }^{1}$ Department of Food \\ Safety and Quality, \\ Lithuanian University \\ of Health Sciences, \\ Veterinary Academy, \\ 18 Tilžès St. \\ Kaunas 47181, Lithuania \\ ${ }^{2}$ Food Institute, \\ Kaunas University of Technology, \\ 19 Radvilenu St., \\ Kaunas 51180, Lithuania
}

\begin{abstract}
Little information is available regarding possible synergistic or antagonistic biochemical interactions among different bioactive substances. The objective of this study was to investigate interactions between flavonoid (taxifolin, TXF), essential oil (linalool, LN), dipeptide (carnosine, CAR), vitamin (ascorbic acid, AA), lactic acid (LA), and their mixtures on cell apoptosis and proliferation-related variables in the human cervical cancer HeLa cells. The effect of the bioactive components on the viability of cultured cells was determined using the MTT assay, and the indirect quantification of cell death was determined with crystal violet dye. Using the MTT method, we found that LA $(0.4 \mu \mathrm{M}$, $0.2 \mu \mathrm{M}$ and $0.1 \mu \mathrm{M})$, TXF ( $1.0 \mathrm{mM}, 0.5 \mathrm{mM}$ and $0.3 \mathrm{mM})$ and CAR (50.0 mM, $25.0 \mathrm{mM}$ and $13.0 \mathrm{mM}$ ) induced acute cytotoxic effects of HeLa cells after $24 \mathrm{~h}$ of treatment $(P \leq 0.05)$. The combination of the three compounds mixture (TXF, CAR and AA or LA) resulted in a significant lower percentage of cells number than the cells treated with that's substances alone in different concentrations $(P<0.05)$. Our study demonstrated that combination treatment with CAR+TXF and addition of acids is able to induce intracellular acidification in cells, and to inhibit the viability of the cancer HeLa cells.
\end{abstract}

Keywords: taxifolin, carnozine, linalool, lactic acid, ascorbic acid, HeLa cells

\section{INTRODUCTION}

Cancer is the second leading cause of death globally, and was responsible for 8.8 million deaths in 2015. Globally, nearly one in six deaths is due to cancer. Determining the goals of treatment and palliative care is an important first step, and health services should be integrated and people-centred. The primary goal is generally to cure cancer or to

\footnotetext{
* Corresponding author. Email: anita.rokaityte@lsmuni.lt
}

considerably prolong life. Improving the patient's quality of life is also an important goal (World Health Organization, 2017). Many types of cancer are effectively treated with chemotherapy. However, high toxic effects of chemotherapeutic drugs causing a severe reduction in quality of life are still formidable problems in clinical medicine (Rein, Kurbacher, 2001). Therefore, it is important to develop novel potent, but low toxic anti-cancer reagents, including natural products. 
Multidrug treatments are increasingly important in medicine and for probing biological systems. As a result, combination therapy is becoming an increasingly important treatment strategy because multidrug can maximize the therapeutic effect and overcome potential mechanisms of drug resistance as they can modulate different signaling pathways in cancer cells (Qi et al., 2016; Xu et al., 2015; Morton et al., 2014; Lee et al., 2014). When used alone, flavonoids and other antioxidants could produce beneficial, detrimental, or insignificant effects in cancer patients, while if they are combined with other anticancer compounds (i.e., natural compounds or chemotherapy drugs), their effects are more likely to be beneficial or at least not harmful (Boik, 2001).

In this study, we selected for investigating the anticancer effect of such different substances as flavonoid (taxifolin, TXF), essential oil (linalool, LN), dipeptide (carnosine, CAR), vitamin (ascorbic acid, AA), lactic acid (LA), and their mixtures in the cells of human cervical cancer HeLa. Published articles reveal that all these chosen substances are capable of inhibiting the growth of cancer cells in vitro and in vivo (Bao et al., 2018; Chang et al., 2015; Jana et al., 2014; Xia et al., 2014; Russo et al., 2013; Horii et al., 2012; Clere et al., 2011). However, many studies focus on interactions between specific substances; little is known about the system properties of the combination of these substances. Two or three substances may have no interaction, or they may interact synergistically or antagonistically to increase or suppress their individual effects. In this study, acid was chosen because the resulting acidification of the cytosol may create optimal conditions for massive activation of protease and other very dangerous lytic enzymes, thus leading to cell death through a sort of auto digestion (Fais et al., 2007). Besides, nanotechnology data identified peptides able to selectively insert into the membrane of cancer cells only at acidic pH (Andreev et al., 2007). Also the location of flavonoids inside membranes depends strongly on $\mathrm{pH}$, the lower the $\mathrm{pH}$, the lower the deprotonation state and the deeper the penetration (Košinová et al., 2012; Movileanu et al., 2000).

The presence of multiple components in the mixtures increased the complexity of the screening assay involving cell culture technique. This study was thus conducted to determine the cytotoxic effect of different kinds of substances and their mixtures on HeLa cells by different methods.

\section{MATERIALS AND METHODS}

Preparation of bioactive component solutions. TXF ( $\geq 85.0 \%)$, LN (97.0\%), CAR (99.0\%), AA ( $\geq 99.0 \%)$ and LA (50.0\%), were purchased from Sigma-Aldrich Chemie $\mathrm{GmbH}$ (Steinheim, Germany) and kept at $4^{\circ} \mathrm{C}$, except CAR, which was kept at $-20^{\circ} \mathrm{C}$. TXF (from 1.0 to $0.07 \mathrm{M}$ ) and CAR (from 50.0 to $3.0 \mathrm{mM}$ ) were dissolved in dimethylsulfoxide (DMSO) (Sigma-Aldrich, Germany) and diluted in the Minimal Essential medium (MEM) with sodium bicarbonate and L-glutamine (Sigma-Aldrich, Germany). Meanwhile, LIN (from 0.4 to $0.03 \mu \mathrm{M}$ ), AA (from 20.0 to $1.3 \mathrm{mM}$ ) and LA (from 0.4 to $0.03 \mu \mathrm{M}$ ) were only diluted in the cell culture medium.

The stock solutions were filtered under aseptic conditions through $0.22 \mu \mathrm{m}$ Q-MAX ${ }^{\odot}$ Syringe Filter (Denmark) and stored at $-20^{\circ} \mathrm{C}$ prior to use. Before test, the stock solutions were kept in dark at room temperature.

HeLa cells. Human Cervical Carcinoma (HeLa) cells were obtained from the Institute of Cardiology at the Lithuanian University of Health Sciences (Lithuania). The cells were cultivated in MEM with sodium bicarbonate and L-glutamine supplemented with $10.0 \%$ FCS (foetal calf serum) (Sigma-Aldrich, Germany) and $1.0 \%$ penicillin $(100.0 \mathrm{U} / \mathrm{ml}) /$ streptomycin $(100.0 \mu \mathrm{g} / \mathrm{mL})$ (Sigma-Aldrich, Germany). The cells were maintained as monolayer in $75 \mathrm{~cm}^{2}$ cell culture flasks (TPP, Sweden) in an incubator at $37^{\circ} \mathrm{C}$ and $98.0 \%$ relative humidity, in an atmosphere of $5.0 \% \mathrm{CO}_{2}$. The cells were subcultured twice weekly with $0.025 \%$ trypsin/ EDTA in phosphate-buffered saline (PBS) (Sigma-Aldrich, Germany) with a seeding density of $4 \times 10^{5}$ cells $/ \mathrm{mL}$. 
Cell viability assay. Single cell suspension was counted using a Neubauer hemocytometer (Neubauer improved, Heinz Herenz Medizinalbedarf, Germany) and resuspended to $2.5 \times 10^{5}-3.0 \times 10^{5}$ cells $/ \mathrm{mL}$. A volume of $100.0 \mu \mathrm{L}$ of the cell suspension was added to each well of 96-well microtiter plate (TPP, Sweden) and incubated for $24 \mathrm{~h}$. After incubation, $50.0 \mu \mathrm{L}$ of the stock solution was incubated with HeLa cells for $24 \mathrm{~h}$. The control stock solution contained DMSO and MEM. For ensuring reliability, the assay was done in triplicate for each stock solution.

The MTT assay. The effect of the bioactive components on the viability of cultured cells was determined using the MTT assay according to Berg (Berg et al., 1990) with a little modification, which was the standard for assessing toxicity of compounds in cell culture. 3-(4,5-dimethylthiazol-2-yl)-2,5-diphenyltetrazolium bromide (MTT) salt (Sigma-Aldrich, Germany) was dissolved in $0.14 \mathrm{M} \mathrm{PBS}(\mathrm{pH} 7.4)$ at $0.5 \mathrm{mg} / \mathrm{mL}$ and filtered using a $0.22 \mu \mathrm{m}$ pore size. After $24 \mathrm{~h}$ incubation period, the medium was removed, $50.0 \mu \mathrm{l}$ of the MTT solution was added to each well of 96-well microtiter plate, mixed thoroughly with plate shaker for $1 \mathrm{~min}$, and the plate was again placed in the incubator at $37^{\circ} \mathrm{C}$ and $98.0 \%$ relative humidity, in an atmosphere of $5.0 \% \mathrm{CO}_{2}$. After $2 \mathrm{~h}$ incubation, a $100.0 \mu \mathrm{l} 96^{\circ}$ ethanol was added to each well and mixed thoroughly in order to dissolve the formed blue crystals of formazan. The plate was shaken for $15 \mathrm{~min}$ and incubated for $15 \mathrm{~min}$. The optical density of wells was measured by Multiskan MS spectrophotometer (Finland) at wavelength of $540 \mathrm{~nm}$ and $580 \mathrm{~nm}$. The effect of bioactive component solutions on mitochondrial metabolic activity was calculated as a percentage of metabolic activity of the cells treated with bioactive component solutions against control cells.

Crystal violet $(\mathrm{CV})$ staining. The indirect quantification of cell death determination method is the staining with crystal violet dye (Carl Roth GmbH, Germany), which binds to proteins and DNA (Chiba et al., 1998) with a slight modification. After appropriate treatments, the growth medium was removed and fixed with $40.0 \mu \mathrm{L} 0.1 \%$ crystal violet solution in $20.0 \%$ ethanol and added to each well of 96-well microtiter plate. The plate was shaken for $30 \mathrm{~min}$. After $0.1 \%$ crystal violet solution in $20.0 \%$ ethanol was removed and cells were washed with water 5-7 times. Before measurement, the dye was solubilised with $50.0 \mu \mathrm{l}$ $0.1 \%$ acetic acid solution in $50.0 \%$ ethanol and mixed in shaker for 2-3 min. The optical density proportional to the cell number was measured by Multiskan MS spectrophotometer (Finland) at wavelength of $570 \mathrm{~nm}$ and $620 \mathrm{~nm}$.

The cell viability (\%) was calculated according to the following equation:

$$
\text { Cell viability }(\%)=\frac{A_{\text {test }}}{A_{\text {control }}} \times 100
$$

where $A_{\text {test }}$ is the absorbance of treated cells and $A_{\text {control }}$ is the absorbance of the untreated cells.

Statistical analysis of the data. Data were statistically analysed using the SPSS 20.0 software (SPSS Inc., Chicago, Illinois, USA). Differences between dates were evaluated by the analysis of variance method (one-way ANOVA) with a significant level of $P \leq 0.05$. Multiple comparisons were estimated by Fishers Least Significant Difference Method, and Dunnett's test was applied when the control group was present. Pearson correlation test was considered reliable when $P \leq 0.01$.

\section{RESULTS AND DISCUSSION}

The MTT assay is based on the reduction of MTT into formazan crystals by the living cells. The intracellular reducing power is mainly provided by $\mathrm{NAD}(\mathrm{P}) \mathrm{H}$ which is derived from dehydrogenase activity in mitochondria, endoplasmic reticulum, and plasma membrane (Stockert et al., 2012; Bernas, Dobrucki, 2000).

As seen in Figure 1, the viability of HeLa cells depended on single natural substances and varied according to their concentration. LA, TXF, and CAR induced acute cytotoxic effects, which were demonstrated by significant degeneration of HeLa cells after $24 \mathrm{~h}$ of treatment. The three highest LA concentrations $(0.4 \mu \mathrm{M}, 0.2 \mu \mathrm{M}$, 


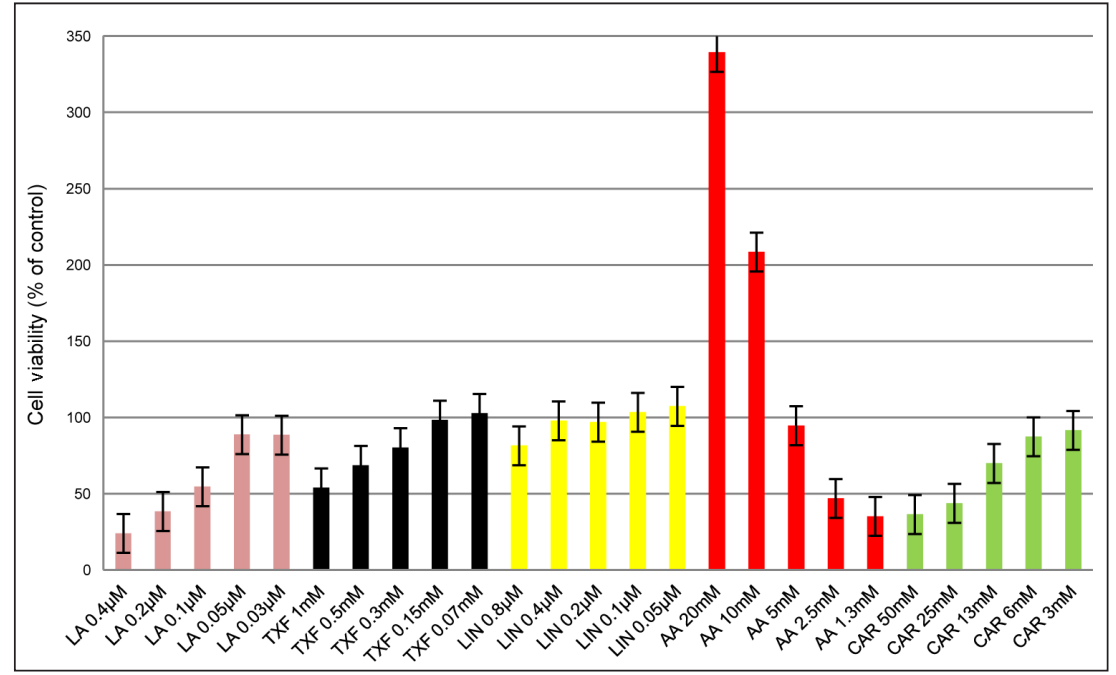

Fig. 1. Effect of different concentrations of LA, TXF, LIN, AA and CAR on the MTT tetrazolium reduction in a HeLa cells

and $0.1 \mu \mathrm{M})$ tested induced acute cytotoxic effects $(P<0.05)$. The treatment of $0.06 \mathrm{mM}$ and $0.03 \mathrm{mM}$ of LA did not show significant proliferation inhibition. Correlation analysis revealed a strong negative relationship between LA concentrations and the number of HeLa cells $(r=-0.907$, when $P \leq 0.01)$. Normalizing cancergenerated LA and resultant acidification and focusing on an altered metabolic pathway may lead to cancer inhibition. Several small AA molecules exhibit promising anticancer activity in vitro and in vivo, as a single agent or in combination with other therapeutic modalities. Inhibition of LA generation of cancers may lead to inhibition of proliferation of cancerous cells by dual pathway via energy depletion, and by reduction of their immunosuppressive activity in the tumour micro-environment (Dhup et al., 2012).

It has been reported that CAR contributes to tumour growth and metabolism, highlighting the critical importance of carnosine's antitumor genic effect (Horii et al., 2012; Iovine et al., 2012). However, it has been suggested that carnosine is involved in cell proliferation, cell cycle arrest, cell apoptosis, and even the glycolytic energy metabolism of certain tumour cells (Sale et al., 2013). In this study, CAR at the concentrations of $50.0 \mathrm{mM}, 25.0 \mathrm{mM}$, and $13.0 \mathrm{mM}$ markedly reduced cell viability to $36.38 \%, 43.70 \%$, and $69.84 \%$ of control, respectively. Correlation analysis revealed a strong negative relationship between CAR concentrations and the num- ber of HeLa cells $(r=-0.923$, when $P \leq 0.01)$. The result of this study is consistent with a previous report regarding the cytotoxicity of CAR to HeLa cancer cells (Bao et al., 2018).

Flavonoids exert their anticancer action by affecting key mechanisms involved in cancer pathogenesis. They are effective antioxidant and anti-inflammatory agents. In initial stages, they inhibit metabolic activation of carcinogens. In progression phases, they induce apoptosis, inhibit angiogenesis, cancer cell proliferation and tumour metastasis; they also modulate multidrug resistance (Clere et al., 2011). Using the MTT method, we found that treatment of HeLa cells with TXF of $1.0 \mathrm{mM}, 0.5 \mathrm{mM}$ and $0.3 \mathrm{mM}$ concentrations significantly inhibited HeLa cells after $24 \mathrm{~h}$ of treatment $(P<0.05)$. Correlation analysis revealed a strong negative relationship between TXF concentrations and the number of HeLa cells $(r=-0.956$, when $P \leq 0.01)$. The result of this study is consistent with a previous report regarding the cytotoxicity of TXF on mammalian cancer cells (Zhang et al., 2013).

$\mathrm{LN}$ is one such compound that has been reported to inhibit the growth of various human cancer cells by causing apoptotic cell death (Jana et al., 2014; Russo et al., 2013). LN acts mainly as an anti-lipoperoxidant agent. Besides, Chang et al. (2015) obtained results demonstrating that LIN produced a cytotoxic effect by inducing the cells to undergo apoptosis, triggering cell death. The result of this study 
showed that only the highest test concentration of LIN (from 0.8 to $0.2 \mu \mathrm{M}$ ) had a weak effect on the reduction of MT. Correlation analysis revealed a strong negative relationship between $\mathrm{LN}$ concentrations and the number of HeLa cells $(r=-0.962$, when $P \leq 0.01)$.

The highest tested AA concentrations (20.0 $\mathrm{mM}$ and $10.0 \mathrm{mM}$ ) induced false negative results, which were demonstrated by significant regeneration of HeLa cells after $24 \mathrm{~h}$ of treatment. One of the possible causes of false results could be chemical interactions between the AA and the MTT indicator. The reductive potential of AA manifests itself due to its enediol group. The phosphorylated derivative of AA showed no interference with the MTT assay because the enediol group was linked to a phosphate group. Moreover, it was reported that in $\mathrm{pH}-$ buffered media lacking cells, MTT is reduced spontaneously to formazanby amitraz (an acaricide), the absorbance being proportional to both MTT concentration and incubation time (Bruggisser et al., 2002). The result of this study is consistent with a previous report by Natarajan et al. (2000) who also noted that AA can directly interfere with the MTT tetrazolium assay.

We proposed that in low concentrations LA may influence the cytotoxic effect of TXF and CAR on the cancer cells; therefore, we evaluated the combinatory effect of TXF, LA, LIN, and CAR on HeLa cell proliferation using the MTT assay. A significant decrease in the percentage of proliferating cells was observed with LA alone, but further addition of TXF and CAR resulted in a slightly lower percentage of proliferating cells (Fig. 2).

Research supports the idea that the effect of the sum of individual drugs may be less effective than drug combinations (Ma et al., 2014). Mixtures of TXF $(0.15 \mathrm{mM})+\mathrm{LA}(0.06 \mu \mathrm{M})$ resulted in a slightly lower percentage of proliferating cells (percentage of control - 69.84\%) than an individual substance (percentage of control $98.27 \%$ and $88.78 \%$, TXF $(0.15 \mathrm{mM})$ and LA $(0.06 \mu \mathrm{M})$, respectively) $(P<0.05)$. Besides, the growth inhibitory effect of $0.4 \mu \mathrm{M} \mathrm{LA}$ in combination with $1.0 \mathrm{mM}$ TXF (\% of control $34.82 \%$ ) was approximately twice the effect than treatment with TXF alone (\% of control $53.86 \%)(P<0.05)$.

The HeLa cells treated with combination of three compound mixtures (TXF, LA and CAR) resulted in a significantly lower percentage of proliferating cells than the cells treated with these substances individually in different concentrations $(P<0.05)$. The HeLa cells treated with a combination of the three compounds mixtures (TXF, LA and LIN) resulted in a slightly lower percentage of proliferating cells than treated with LA alone, but higher than treated with TXF and LIN alone in different concentrations.

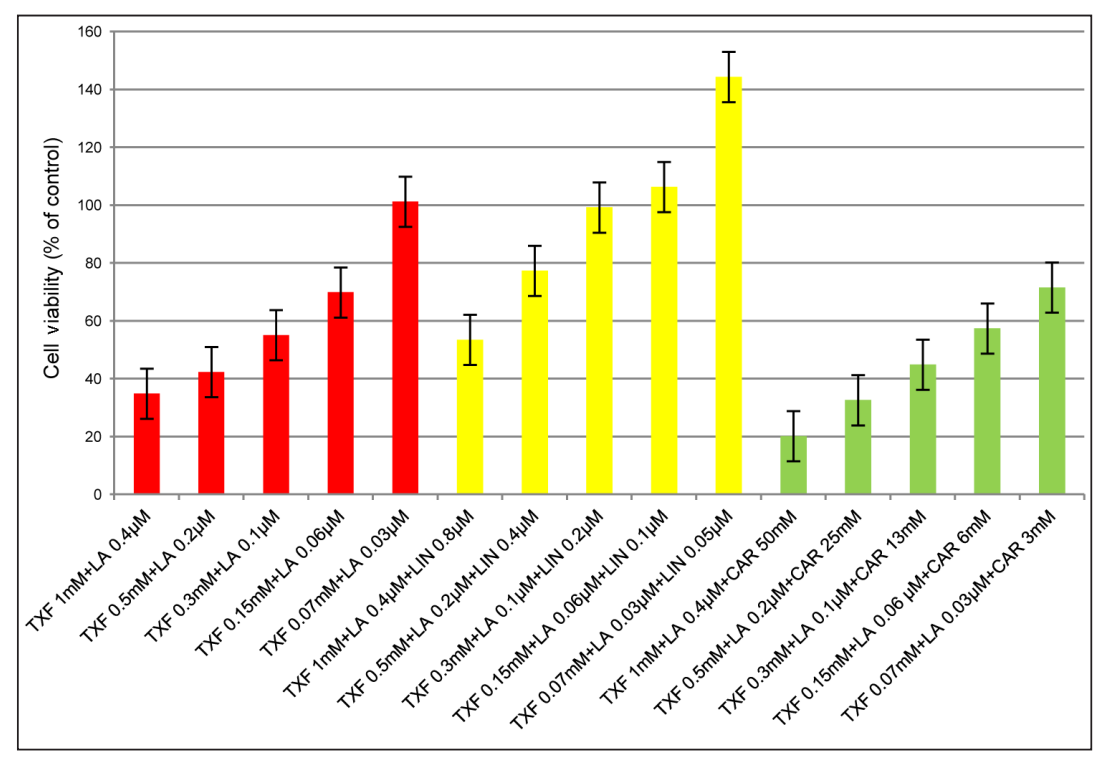

Fig. 2. Effect of different combinations of TXF, LA, LIN and CAR on the MTT tetrazolium reduction in HeLa cells 
Research supports the idea that several drug delivery systems that intercalate multiple drugs to deliver specific site of tumours have been proposed with a view of improving antitumour activity and potentially overcoming drug resistance, while also reducing the doses of individual drugs (Liu et al., 2014; Yan et al., 1991). It has been suggested that many naturally occurring compounds act as "enhancers" or reduce the side effects of other anti-cancer therapeutic drugs by increasing the therapeutic effects of the key anti-cancer agent (Liu et al., 2012). In this study, results showed that a weakly acidic medium markedly augments anti-proliferation activity of LIN and CAR.

As seen in Fig. 3, the number of HeLa cells depends on single natural substances and varies according to their concentration. LA, TXF, and AA induced acute cytotoxic effects that were demonstrated by significant degeneration of HeLa cells after $24 \mathrm{~h}$ of treatment. LA at concentrations of $0.44 \mu \mathrm{M}, 0.22 \mu \mathrm{M}$, and $0.11 \mu \mathrm{M}$ markedly reduced the number of HeLa cells to, respectively, $21.82 \%, 31.99 \%$, and $47.26 \%$ compared with control cells. However, the lowest LA concentration $(0.03 \mu \mathrm{M})$ significantly increased the cell number (percentage of control - 119.73\%). Fais et al. (2007) support the idea that weakly acidity could have a role in the resistance of cancer cells to chemotherapy, proliferation, and metastatic behaviour.

TXF at concentrations of $1.0 \mathrm{mM}, 0.5 \mathrm{mM}$, and $0.3 \mathrm{mM}$ markedly reduced the number of,
HeLa cells to, respectively, $26.70 \%, 41.65 \%$ and $68.27 \%$ compared with control cells. However, the lowest TXF concentration $(0.07 \mathrm{mM})$ had significant increased cell number (percentage of control - 121.24\%). This may have resulted from inconsistent reduction by flavonol of the metabolic compound between analyses with fluctuating variables, such as the amount of flavonols remaining in the well during incubation and the numbers of cells between analyses. Forbes et al. (2014) find that flavonols used with the crystal violet assays significantly masks the effects on cell viability readings at lower concentrations, but at higher flavonol concentrations this interference appears to be minimal.

AA is generally considered an antioxidant at normal physiological levels (approx. 60.0$80.0 \mu \mathrm{M})$ but considered a pro-oxidant at much higher concentrations ( $>1.0 \mathrm{mM}$ ) (Roberts et al., 2015). Contrary to this, Azqueta et al. (2013) did not find a significant pro-oxidant or antiproliferative effect of AA on the HeLa cell line, which in relation to other studies was probably due to the low concentrations of AA utilized in the study $(\leq 200.0 \mu \mathrm{M})$. In our study, results indicate that $20.0 \mathrm{mM}, 10.0 \mathrm{mM}$, and $5.0 \mathrm{mM}$ of AA markedly reduced the number of HeLa cells $(P<0.05)$. The result of this study is consistent with a previous report by Roberts et al. (2015), who also noted that $10.0 \mathrm{mM}$ and $7.0 \mathrm{mM}$ of AA induce cell death via an extrinsic and intrinsic apoptotic pathway.

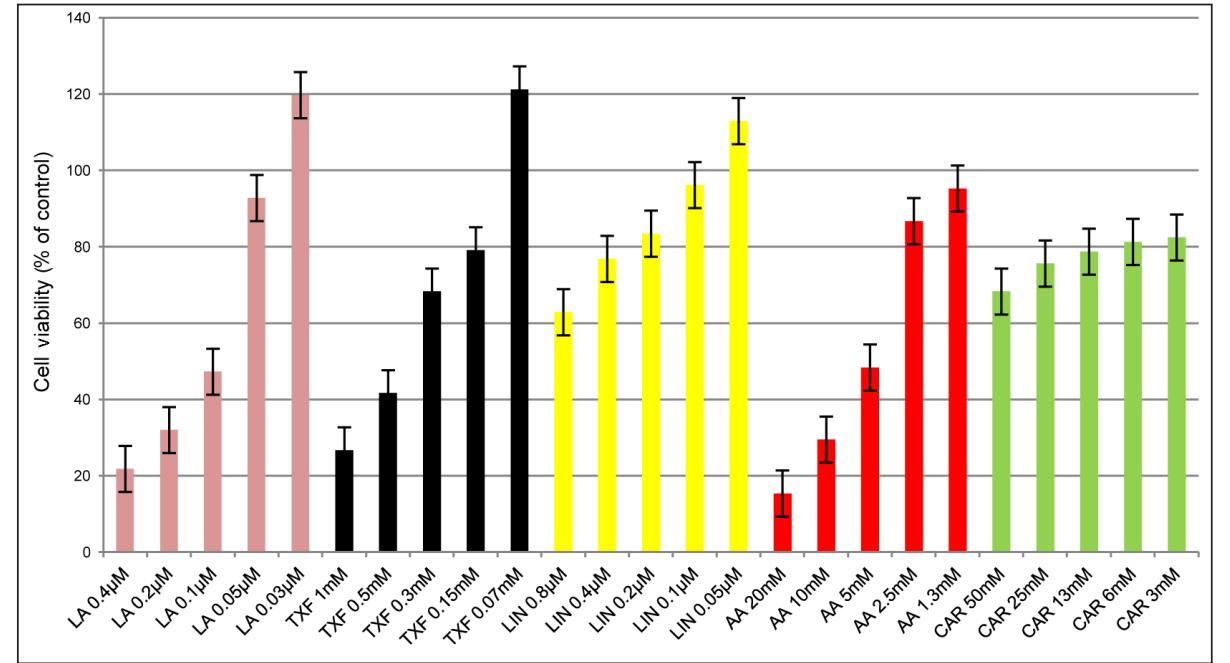

Fig. 3. The cytotoxicity effect of different concentrations of LA, TXF, LIN, AA and CAR of HeLa cells. The number of cells was determined by the crystal violet staining method 
We evaluated the combinatory effect of LA, TXF, LIN and CAR and their mixtures on the number of HeLa cell using the crystal violet assay (Fig. 4). A significant decrease in the percentage of the cell number was observed with TXF+LA mixture in all cases, but a synergetic effect was determined only between the lowest concentrations $(P<0.05)$. Also, a significant synergistic effect the of three compounds mixtures was determined (TXF, LA and CAR) in all cases $(P \leq 0.05)$. These three substances mixtures interacted synergistically to increase their individual effects. This may be attributed to the acidic medium because the location of peptides and flavonoids inside membranes depends strongly on $\mathrm{pH}$ : the lower the $\mathrm{pH}$, the lower the deprotonation state, and the deeper the penetration (Košinová et al., 2012; Andreev et al., 2007; Reshetnyak et al., 2006; Movileanu et al., 2000). Our study confirmed this findingthat a mixture of TXF+CAR substances has a synergistic effect (Fig. 5) but smaller than used together with LA.

However, a mixture of TXF, LA and LIN had antagonistic interactions suppressing their individual effects on HeLA cells. Mechanisms of interaction that produced antagonistic effects were less studied. But it is clear that what

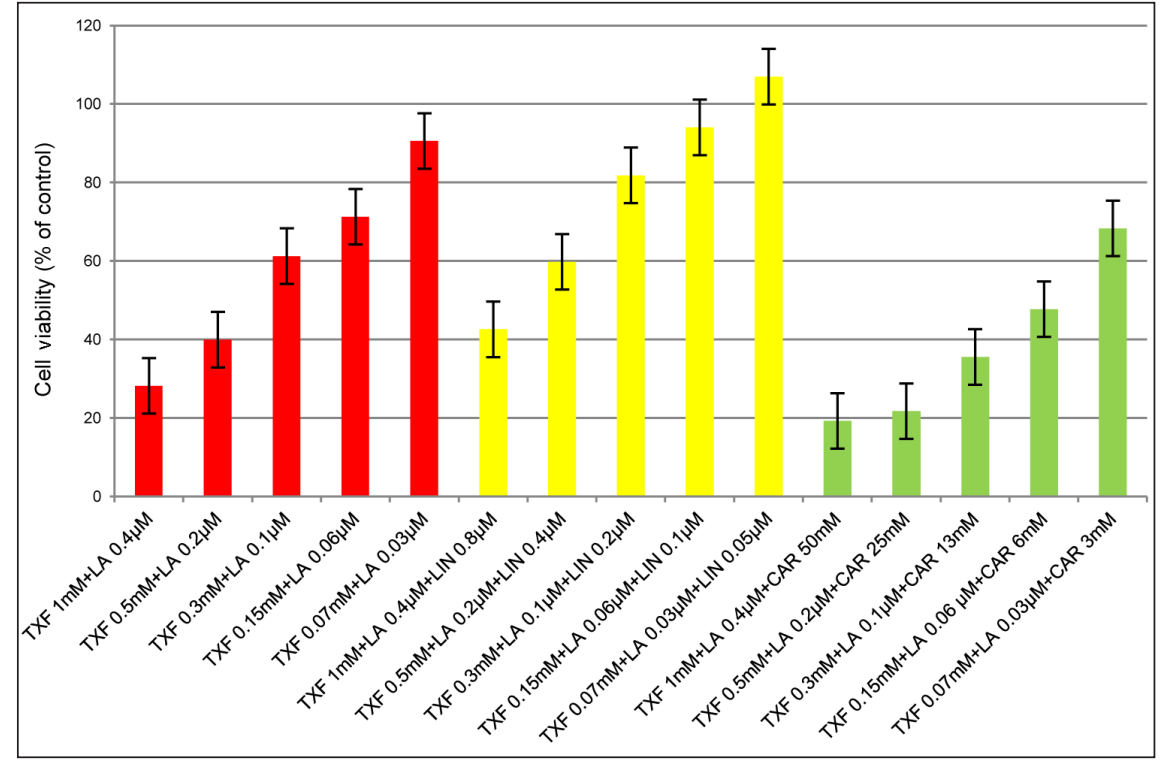

Fig. 4. The cytotoxicity effect of different concentrations of TXF, LA, LIN and CAR of HeLa cells. The number of cells was determined by the crystal violet staining method

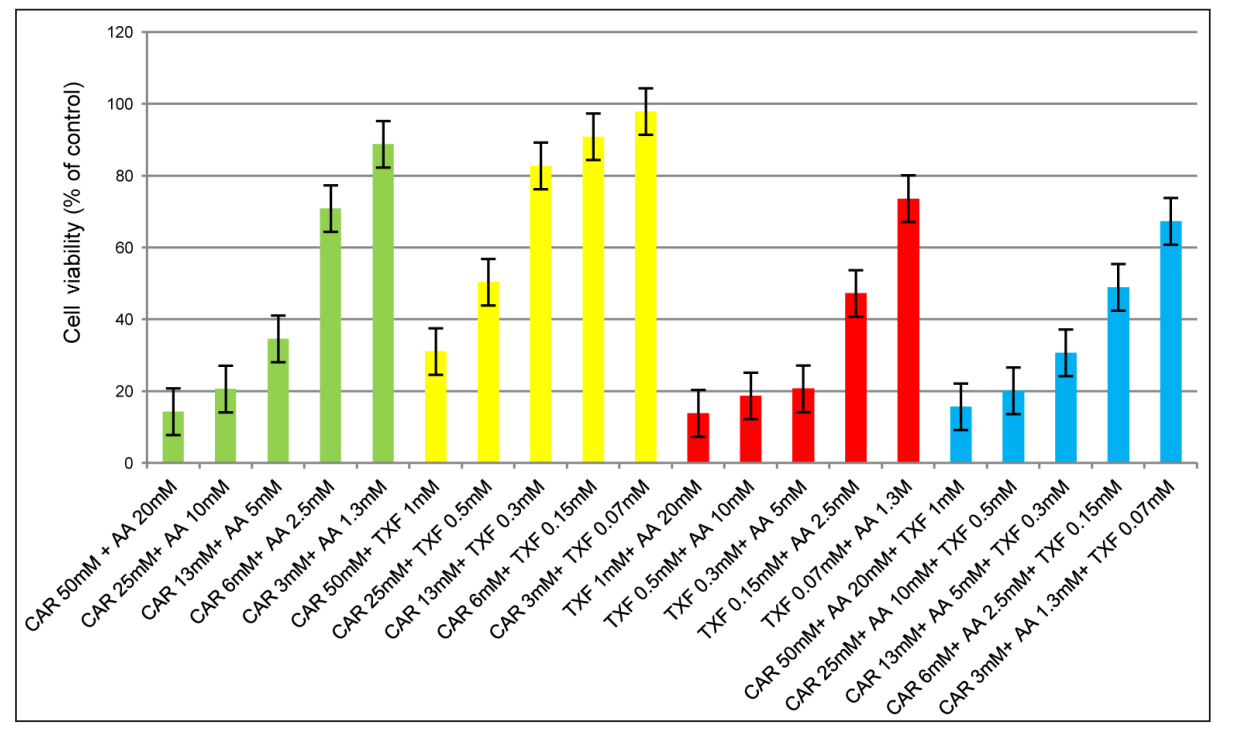

Fig. 5. The cytotoxicity effect of different concentrations of CAR, AA and TXF of HeLa cells. The number of cells was determined by the crystal violet staining method 
might be a synergistic combination in some circumstances might actually be antagonistic in others - it all depends on the context.

Mixtures of $\mathrm{AA}+\mathrm{TXF}$ and $\mathrm{AA}+\mathrm{TXF}+\mathrm{CAR}$ induced acute cytotoxic effects, which were demonstrated by significant degeneration of HeLa cells after $24 \mathrm{~h}$ of treatment (Fig. 5). There is evidence that AA has flavonoid protective and enhancing activities (Jan et al., 1991; Kandaswami et al., 1993), probably due to the reduction of oxidized flavonoid and regeneration of flavonol. A cooperative action between AA and flavonoid could be beneficial in enhancing the ability of the latter to rescue cells from damage induced by oxidative stress. Besides, AA was found to enhance the cytoprotective effects of quercetin and rutin against oxidative stress-induced death of human skin fibroblasts. AA both lowered EC50 and prolonged the time over which the flavonoid was active in rescuing cells from oxidative injury. Such an interaction could be evidenced as a synergistic effect providing a constant resupply of flavonoid acting as radical scavenger and limiting the amount of the aroxyl radical decaying by a second-order reaction (Bors et al., 1995). Roomi et al. (2006) showed that AA, when in a nutrient mixture with lysine, proline, and green tea extract, caused a significant anti-proliferative effect on the growth of HeLa cells; however, the combination of AA with other compounds makes it impossible to distinguish the effect of a single ingredient.

Together, the two compounds reduced more the proliferation and viability of cells and enhanced the induction of apoptosis compared to each separately (Mertens-Talcott et al., 2003). Mertens-Talcott et al. (2003) investigated the combinational effect of quercetin and ellagic acid on cell death in the MOLT- 4 human leukemia cell line. In another study, the combination treatment of the human gut (HuTu-80 and Caco-2) and breast cancer cells (PMC42) with quercetin and kaempferol was more effective than the additive effects of each flavonol (Ackland et al., 2005). In our case, the synergetic action of different substances was influenced by selection of acid and its concentration. Combination of AA with two compounds CAR and
TXF has a significantly higher effect than this combination with LA $(P<0.05)$.

\section{CONCLUSIONS}

The present study demonstrated that combination treatment with CAR+TXF and addition of acids is capable of inducing intracellular acidification in cancer cells, and of inhibiting the viability of human cervical cancer HeLa cells. Therefore, it is proposed that combined treatments with $\mathrm{AA}+\mathrm{CAR}+\mathrm{TXF}$ and $\mathrm{LA}+\mathrm{CAR}+\mathrm{TXF}$ may enhance antitumor activity compared with single-agent treatment. However, phytochemical studies together with investigations of biological activity in vivo are required for a complete understanding of medical applications. Identifying potential interactions among these compounds may help to define the efficiency of foods containing these substances in cancer prevention as related to structure-function activity of the compounds.

\section{ACKNOWLEDGEMENTS}

The study was partially financed by the Research Foundation of the Lithuanian University of Health Sciences.

Received 30 May 2018

Accepted 15 January 2019

\section{References}

1. Ackland ML, van de Waarsenburg S, Jones R. Synergistic antiproliferative action of the flavonols quercetin and kaempferol in cultured human cancer cell lines. In vivo. 2005; 19 : 69-76.

2. Andreev OA, Dupuy AD, Segala M, Sandugu S, Serra DA, Chichester CO. Mechanism and uses of a membrane peptide that targets tumors and other acidic tissues in vivo. Proc Natl Acad Sci USA. 2007; 104(19): 7893-8.

3. Azqueta A, Costa S, Lorenzo Y, Bastani NE, Collins AR. Vitamin C in cultured human 
(HeLa) cells: lack of effect on DNA protection and repair. Nutrients. 2013; 5: 1200-17.

4. Bao Y, Ding S, Cheng J, Liu Y, Wang B, Xu H, Shen Y, Lyu J. Carnosine inhibits the proliferation of human cervical gland carcinoma cells through inhibiting both mitochondrial bioenergetics and glycolysis pathways and retarding cell cycle progression. Integr Cancer Ther. 2018; 17(1): 80-91.

5. Berg K, Hansen MB, Nielsen SE. A new sensitive bioassay for precise quantification of interferon activity as measured via the mitochondrial dehydrogenase function in cells (MTT-method). APMIS. 1990; 98(2): 156-62.

6. Bernas T, Dobrucki JW. The role of plasma membrane in bioreduction of two tetrazolium salts, MTT, and CTC. Arch Biochem Biophys. 2000; 380(1): 108-16.

7. Boik J. Natural compounds in cancer therapy: promising nontoxic antitumor agents from plant \& other natural sources. Princeton, Minnesota: Oregon Medical Press. 2001; p. 521.

8. Bors W, Michel C, Schikora S. Interaction of flavonoids with ascorbate and determination of their univalent redox potentials: a pulse radiolysis study. Free Radic Biol Med. 1995; 19(1): 45-52.

9. Bruggisser R, von Daeniken K, Jundt G, Schaffner W, Tullberg-Reinert $H$. Interference of plant extracts, phytoestrogens and antioxidants with the MTT tetrazolium assay. Planta Med. 2002; 68(5): 445-8.

10. Chang MY, Shieh DE, Chen CC, Yeh CS, Dong HP. Linalool induces cell cycle arrest and apoptosis in leukemia cells and cervical cancer cells through CDKIs. Int J Mol Sci. 2015; 16(12): 28169-79.

11. Chiba K, Kawakami K, Tohyama K. Simultaneous evaluation of cell viability by neutral red, MTT and crystal violet staining assays of the same cells. Toxicol in Vitro. 1998; 12(3): 251-8.

12. Clere N, Faure S, Martinez MC, Andriantsitohaina R. Anticancer properties of flavonoids: roles in various stages of carcinogenesis. Car- diovasc Hematol Agents Med Chem. 2011; 9(2): 62-77.

13. Dhup S, Dadhich RK, Porporato PE, Sonveaux P. Multiple biological activities of lactic acid in cancer: influences on tumor growth, angiogenesis and metastasis. Curr Pharm Des. 2012; 18(10): 1319-30.

14. Fais S, De Milito A, You H, Qin W. Targeting vacuolar $\mathrm{H}+-\mathrm{ATPases}$ as a new strategy against cancer. Cancer Res. 2007; 67(22): 10627-30.

15. Forbes AM, Lin H, Meadows GG, Meier GP. Synthesis and anticancer activity of new flavonoid analogs and inconsistencies in assays related to proliferation and viability measurements. Int J Oncol. 2014; 45(2): 831-42.

16. Horii Y, Shen J, Fujisaki Y, Yoshida K, Nagai K. Effects of L-carnosine on splenic sympathetic nerve activity and tumor proliferation. Neurosci Lett. 2012; 510(1): 1-5.

17. Iovine B, Iannella ML, Nocella F, Pricolo MR, Bevilacqua MA. Carnosine inhibits KRASmediated HCT116 proliferation by affecting ATP and ROS production. Cancer Lett. 2012; 315(2): 122-8.

18. Jan CY, Takahama U, Kimura M. Inhibition of photooxidation of a-tocopherol by quercetin in human blood cell membranes in the presence of hematoporphyrin as a photosensitizer. Biochim Biophys Acta. 1991; 1086(1): 7-14.

19. Jana S, Patra K, Sarkar S, Jana J, Mukherjee G, Bhattacharjee S, Mandal DP. Antitumorigenic potential of linalool is accompanied by modulation of oxidative stress: an in vivo study in sarcoma-180 solid tumor model. Nutr Cancer. 2014; 66(5): 835-48.

20. Kandaswami C, Perkins E, Soloniuk DS, Dnewiecki E, Middleton EJ. Ascorbic acid-enhanced antiproliferative effect of flavonoids on squamous cell carcinoma in vitro. Anticancer Drugs. 1993; 4(1): 91-6.

21. Košinová P, Berka K, Wykes M, Otyepka M, Trouillas P. Positioning of antioxidant quercetin and its metabolites in lipid bilayer membranes: implication for their lipid-peroxidation inhibition. J Phys Chem B. 2012; 116(4): 1309-18. 
22. Lee HJ, Zhuang G, Cao Y, Du P, Kim HJ, Settleman J. Drug resistance via feedback activation of Stat 3 in oncogene-addicted cancer cells. Cancer Cell. 2014; 26(2): 207-21.

23. Liu S, Guo Y, Huang R, Li J, Huang S, Kuang Y, Han L, Jian C. Gene and doxorubicin co-delivery - system for targeting therapy of glioma. Biomaterials. 2012; 33(19): 4907-16.

24. Liu Y, Fang J, Joo KI, Wong MK, Wang P. Codelivery of chemotherapeutics via crosslinked multilamellar liposomal vesicles to overcome multidrug resistance in tumor. PLoS One. 2014; 9(10): 1-10.

25. Ma Y, Liu D, Wang D, Wang Y, Fu Q, Fallon JK, Yang X, He Z, Liu F. Combinational delivery of hydrophobic and hydrophilic anticancer drugs in single nanoemulsions to treat MDR in cancer. Mol Pharm. 2014; 11(8): 2623-30.

26. Mertens-Talcott SU, Talcott ST, Percival SS. Low concentrations of quercetin and ellagic acid synergistically influence proliferation, cytotoxicity and apoptosis in MOLT-4 human leukemia cells. J Nutr. 2003; 133(8): 2669-74.

27. Morton SW, Lee MJ, Deng ZJ, Dreaden EC, Siouve E, Shopsowitz KE, Shah NJ, Yaffe MB, Hammond PT. A nanoparticle-based combination chemotherapy delivery system for enhanced tumor killing by dynamic rewiring of signaling pathways. Sci Signal. 2014; 7(325): $1-27$.

28. Movileanu L, Neagoe I, Flonta ML. Interaction of the antioxidant flavonoid quercetin with planar lipid bilayers. Int J Pharm. 2000; 205(1-2): 135-46.

29. Natarajan M, Mohan S, Martinez BR, Meltz ML, Herman TS. Antioxidant compounds interfere with the 3-(4,5-dimethylthiazol-2-yl)-2,5-diphenyltetrazolium bromide cytotoxity assay. Cancer Detect Prev. 2000; 24(5): 405-14.

30. Qi J, Zhang Y, Gou Y, Lee P, Wang J, Chen S, Zhou Z, Wu X, Yang F, Liang H. Multidrug delivery systems based on human serum albumin for combination therapy with three anticancer agents. Mol Pharm. 2016; 13(9): 3098105.
31. Rein DT, Kurbacher CM. The role of chemotherapy in invasive cancer of the cervix uteri: current standards and future prospects. Anticancer Drugs. 2001; 12(10): 787-95.

32. Reshetnyak YK, Andreev OA, Lehnert U, Engelman DM. Translocation of molecules into cells by $\mathrm{pH}$-dependent insertion of a transmembrane helix. Proc Natl Acad SciUSA. 2006; 103(17): 6460-5.

33. Roberts BM, Fullerton DR, Elliott SL. High concentrations of L-ascorbic acid (Vitamin C) induces apoptosis in a human cervical cancer cell line (HeLa) through the intrinsic and extrinsic pathways. Bios. 2015; 86(3): 134-43.

34. Roomi MW, Roomi N, Ivanov, Kalinovsky T, Niedzwiecki A, Rath M. Inhibition of pulmonary metastasis of melanoma B16FO cells in C57BL/6 mice by a nutrient mixture consisting of ascorbic acid, lysine, proline, arginine, and green tea extract. Exp Lung Res. 2006; 32(10): 517-30.

35. Russo R, Ciociaro A, Berliocchi L, Cassiano MG, Rombola L, Ragusa S, Bagetta G, Blandini F, Corasaniti MT. Implication of limonene and linalyl acetate in cytotoxicity induced by bergamot essential oil in human neuroblastoma cells. Fitoterapia. 2013; 89: 48-57.

36. Sale C, Artioli GG, Gualano B, Saunders B, Hobson RM, Harris RC. Carnosine: from exercise performance to health. Amino Acids. 2013; 44(6): 1477-91.

37. Stockert JC, Blázquez-Castro A, Cañete M, Horobin RW, Villanueva A. MTT assay for cell viability: Intracellular localization of the formazan product is in lipid droplets. Acta Histochem. 2012; 114(8): 785-96.

38. World Health Organization (FAO/WHO). Global Initiative for Cancer Registry Development. International Agency for Research on Cancer. 2017; Available from: http://www. who.int/mediacentre/factsheets/fs297/en

39. Xia J, Chen J, Zhang Z, Song P, Tang W, Kokudo N. A map describing the association between effective components of traditional Chinese medicine and signaling pathways in 
cancer cells in vitro and in vivo. Drug Discov Ther. 2014; 8(4): 139-53.

40. Xu X, Ho W, Zhang X, Bertrand N, Farokhzad O. Cancer nanomedicine: from targeted delivery to combination therapy. Trends $\mathrm{Mol}$ Med. 2015; 21(4): 223-32.

41. Yan Y, Such GK, Johnston APR, Best JP, Caruso $\mathrm{F}$. Engineering particles for therapeutic delivery: prospects and challenges. ACS Nano. 2012; 6(5): 3663-9.

42. Zhang ZR, Al Zaharna $\mathrm{M}$, Wong $\mathrm{MM}$, Chiu SK, Cheung HY. Taxifolin enhances andrographolide-induced mitotic arrest and apoptosis in human prostate cancer cells via spindle assembly checkpoint activation. PLoS One. 2013; 8(1): 1-16.
Anita Rokaitytè, Gintarè Zaborskienè, Violeta Baliukonienè, Jurgita Jovaišienė, Sonata Gustienè

\section{KARNOZINO, TAKSIFOLINO, LINALOLIO IR JŲ MIŠINIŲ CITOTOKSINIO POVEIKIO IVERTINIMAS ŽMOGAUS GIMDOS KAKLE- LIO VĖŽIO (HELA) LĄSTELĖMS}

\section{Santrauka}

Kasmet pasaulyje nustatoma daugiau kaip puse milijono naujų gimdos kaklelio vèžio atvejų, ir tai yra viena dažniausių moterų mirties priežasčių. Straipsnio tikslas yra ivertinti in vitro flavonoido (taksifolino - TXF), eterinio aliejaus (linalolio - LN), dipeptido (karnozino - KAR), vitamino (askorbo rūgšties - AR), pieno rūgšties (PR) ir jų mišinių sąveiką gimdos kaklelio vèžio HeLa ląstelių kultūrų proliferacijai ir apoptozei. Tyrimo metu paaiškejjo, kad HeLa ląstelių gyvybingumas priklauso nuo pasirinktų medžiagų rūšies ir koncentracijos. Ivertinę metabolitinių gyvų ląstelių aktyvumą nustatème, kad didesnès atskirai naudotų PR $(0,4 ; 0,2$ ir 0,1 $\mu \mathrm{M})$, TXF $(1,0 ; 0,5$ ir 0,3 mM) ir $\operatorname{KAR}(50,25$, ir $13 \mathrm{mM}$ ) medžiagų koncentracijos sukelia stiprų citolitinị efektą HeLa ląstelių kultūroms, tačiau poveikis sustiprèja naudojant šių medžiagų mišinius (TXF+KAR ir PR arba AR).

Raktažodžiai: taksifolinas, linalolis, karnozinas, pieno ir askorbo rūgštis, HeLa ląstelès 